\title{
Insulin Receptor Phosphorylation, Insulin Receptor Substrate-1 Phosphorylation, and Phosphatidylinositol 3-Kinase Activity Are Decreased in Intact Skeletal Muscle Strips from Obese Subjects
}

\author{
Laurie J. Goodyear, ${ }^{*}$ Francesco Giorgino, ${ }^{\star}$ L. Adam Sherman, ${ }^{\star}$ Julie Carey, ${ }^{\ddagger}$ Robert J. Smith, ${ }^{*}$ and G. Lynis Dohm \\ *Research Division, Joslin Diabetes Center, Department of Medicine, Brigham and Women's Hospital, and Harvard Medical School, \\ Boston, Massachusetts 02215; and ${ }^{\ddagger}$ Department of Biochemistry, School of Medicine, East Carolina University, Greenville, \\ North Carolina 27858
}

\begin{abstract}
To determine whether the impaired insulin-stimulated glucose uptake in obese individuals is associated with altered insulin receptor signaling, we measured both glucose uptake and early steps in the insulin action pathway in intact strips of human skeletal muscle. Biopsies of rectus abdominus muscle were taken from eight obese and eight control subjects undergoing elective surgery (body mass index 52.9 \pm 3.6 vs $25.7 \pm 0.9$ ). Insulin-stimulated 2 -deoxyglucose uptake was $53 \%$ lower in muscle strips from obese subjects. Additional muscle strips were incubated in the basal state or with $10^{-7}$ $M$ insulin for 2,15 , or $30 \mathrm{~min}$. In the lean subjects, tyrosine phosphorylation of the insulin receptor and insulin receptor substrate-1 (IRS-1), measured by immunoblotting with anti-phosphotyrosine antibodies, was significantly increased by insulin at all time points. In the skeletal muscle from the obese subjects, insulin was less effective in stimulating tyrosine phosphorylation (maximum receptor and IRS-1 phosphorylation decreased by 35 and $38 \%$, respectively). Insulin stimulation of IRS-1 immunoprecipitable phosphatidylinositol 3-kinase (PI 3-kinase) activity also was markedly lower in obese subjects compared with controls (10- vs 35fold above basal, respectively). In addition, the obese subjects had a lower abundance of the insulin receptor, IRS-1, and the p85 subunit of PI 3-kinase (55, 54, and $64 \%$ of nonobese, respectively). We conclude that impaired insulinstimulated glucose uptake in skeletal muscle from severely obese subjects is accompanied by a deficiency in insulin receptor signaling, which may contribute to decreased insulin action. (J. Clin. Invest. 1995. 95:2195-2204.) Key words: insulin action • insulin resistance $\bullet$ obesity $\bullet$ insulin receptor substrate $\cdot$ tyrosine phosphorylation
\end{abstract}

\section{Introduction}

A significant metabolic abnormality in obesity is the diminished ability of insulin-sensitive tissues to take up and metabolize

Address correspondence to Laurie J. Goodyear, Ph.D., Research Division, Joslin Diabetes Center, One Joslin Place, Boston, MA 02215. Phone: 617-732-2573; FAX: 617-732-2650. Francesco Giorgino's present address is Istituto di Clinica Medica, Endocrinologia e Malattie Metaboliche, University of Bari School of Medicine, 70124 Bari, Italy.

Received for publication 24 October 1994 and in revised form 28 December 1994.

J. Clin. Invest.

(C) The American Society for Clinical Investigation, Inc.

$0021-9738 / 95 / 05 / 2195 / 10 \quad \$ 2.00$

Volume 95, May 1995, 2195-2204 glucose (1-3). Skeletal muscle is the primary site of insulinstimulated glucose disposal and has been suggested to be the major tissue responsible for postprandial hyperglycemia in insulin-resistant subjects $(4,5)$. Although the defect in insulinstimulated glucose disposal has been well described in human skeletal muscle, the underlying molecular mechanisms for abnormal insulin responsiveness in this tissue are not clear. It is likely that the impaired insulin action associated with obesity stems from alterations in the expression or function of one or more of the cellular proteins that are components of the insulin receptor signaling pathway, the glucose transport system, or both. In the current investigation we have developed a novel method to study the proximal steps of insulin receptor signaling in intact strips of human skeletal muscle. We have used this method to determine whether human obesity is associated with an alteration in tyrosine phosphorylation of the insulin receptor and insulin receptor substrate-1 (IRS-1) ${ }^{1}$ and in phosphatidylinositol 3-kinase (PI 3-kinase) activity.

Insulin action is initiated through hormone binding to cell surface insulin receptors, which triggers a cascade of intracellular phosphorylation events. Insulin binding to the extracellular $\alpha$ subunit of the receptor results in autophosphorylation of tyrosine residues in the receptor $\beta$ subunit and activation of a tyrosine kinase intrinsic to the $\beta$ subunit (6). The stimulation of receptor kinase activity induces the phosphorylation of nonreceptor proteins $(7,8)$, including IRS-1 (9). Phosphorylation of IRS-1 by the insulin receptor kinase can occur at TyrXXMet (YXXM) and TyrMetXMet (YMXM) motifs (10), which then bind with high affinity to $s r c$-homology 2 domains of cellular proteins, including the $85-\mathrm{kD}$ regulatory subunit of PI 3-kinase (11). PI 3-kinase phosphorylates cellular phosphoinositides at the D-3 position, resulting in the formation of phosphatidylinositol-3-monophosphate, phosphatidylinositol-3,4-bisphosphate, and phosphatidylinositol-3,4,5-trisphosphate (12). An increase in PI 3-kinase activity occurs after activation of several growth factor receptors $(13,14)$ and has been implicated in the regulation of multiple cellular functions $(15,16)$. In insulin-sensitive tissues, such as isolated rat adipocytes (17) and intact rat skeletal muscle $(18,19)$, insulin dramatically increases PI 3-kinase activity in IRS-1 and tyrosine phosphoprotein immunoprecipitates, resulting in an increase in D-3 phosphoinositides $(19,20)$. The precise function of PI 3-kinase activation and generation of the D-3 phosphoinositides by insulin is not clear, but recent

1. Abbreviations used in this paper: BMI, body mass index; IRS-1, insulin receptor substrate-1; NIDDM, non-insulin-dependent diabetes mellitus; PI 3-kinase, phosphotidylinositol 3-kinase; PTPase, protein tyrosine phosphatase. 
studies in cultured cells suggest that enzyme activity may be necessary for insulin-stimulated translocation of glucose transporters $(21-23)$.

Insulin receptor preparations from the skeletal muscle of human subjects have been used to study receptor kinase activity in vitro $(24,25)$. In patients with non-insulin-dependent diabetes mellitus (NIDDM) and obesity, these previous studies have shown variable changes in insulin receptor autophosphorylation, which has been alternatively described as impaired (24) or unchanged (25). In addition, assays of kinase activity toward added (exogenous) substrates reveal consistently decreased activity in these subjects $(24,25)$. Although these studies have described receptor function using isolated receptor preparations, the effects of insulin on receptor phosphorylation, IRS-1 phosphorylation, and PI 3-kinase activity in intact human skeletal muscle preparations are not known. In rat skeletal muscle recent studies have assessed insulin-induced tyrosine phosphorylation of muscle proteins in vivo (26-28). These methods are advantageous in that the manipulation of intact tissue rather than partially purified receptor preparations minimizes procedurally induced changes in receptor function and allows for the measurement of endogenous rather than artificial substrate phosphorylation. In animal models of diabetes and insulin resistance, significant differences between experiments performed in vivo and in vitro have become evident. For example, isolated receptors from streptozotocin-diabetic skeletal muscle demonstrate decreased exogenous substrate kinase activity with histone $\mathrm{H}_{2} \mathrm{~b}$ and angiotensin II as phosphoacceptors (29), whereas streptozotocin-diabetes results in increased tyrosine phosphorylation of IRS-1 in intact muscle tissue $(26,27)$. In addition, whereas insulin receptors from the skeletal muscle of hypercortisolemic rats show normal receptor autophosphorylation and kinase activity in vitro (30), this condition results in decreased receptor tyrosine phosphorylation in vivo (28). Thus, it is crucial to our understanding of insulin action in human tissues to study the insulin signaling pathway in intact skeletal muscle preparations.

In the current study, we have used a new method to measure both glucose uptake and proximal steps in insulin signaling in the same intact human skeletal muscle preparations. This method has been used to measure tyrosine phosphorylation of the insulin receptor and IRS-1, PI 3-kinase activity, and expression of the insulin receptor, IRS-1, and the p85 subunit of PI 3-kinase in intact skeletal muscle of obese individuals. Our results demonstrate that impaired insulin-stimulated glucose uptake in the skeletal muscle of obese patients is associated with decreased activation of the molecules involved in the initial steps of the insulin signaling pathway.

\section{Methods}

Materials. Protein A-Sepharose was from Pierce Chemical Co. (Rockford, IL). Reagents for SDS-PAGE and protein assay kits were from Bio Rad Laboratories (Richmond, CA). ${ }^{125} \mathrm{I}$-labeled protein A was purchased from ICN Biomedical (Costa Mesa, CA). 2- $\left[1,2-{ }^{3} \mathrm{H}(n)\right]$-deoxyD-glucose and $\left[\gamma_{-}{ }^{32} \mathrm{P}\right]$ ATP were from New England Nuclear (Boston, MA). Phosphatidylinositol was from Avanti Polar Lipids Inc. (Alabaster, AL). Anti-PI 3-kinase was purchased from Upstate Biotechnology Inc. (Lake Placid, NY). Other chemicals and reagents were from Sigma Chemical Co. (St. Louis, MO).

Human subjects. The surgical protocol was approved by the East Carolina University Policy and Review Committee on Human Research. Informed consent was obtained from all subjects after a thorough expla- nation of the experimental protocol. Control muscle was obtained from non-obese subjects undergoing hysterectomy. The obese group consisted of severely obese subjects undergoing gastric bypass surgery for treatment of obesity. All subjects were female.

Muscle strip preparation. The method for obtaining the muscle specimens has been described in detail (2). After an overnight fast, the subjects had general anesthesia induced with a short acting barbiturate and maintained with phentanyl and a nitrous oxide-oxygen mixture. Only saline was given intravenously before the muscle biopsy. The abdomen was opened, and $\sim 3 \times 2 \times 2-\mathrm{cm}$ biopsy from the rectus abdominus muscle was clamped, excised, and placed in oxygenated Krebs-Henseleit buffer. The specimen was rapidly transported to the laboratory, where 18 muscle strips weighing $30-40 \mathrm{mg}$ each were teased from the mounted sample. The remaining muscle tissue was frozen in liquid nitrogen.

Glucose transport measurements and muscle incubation and processing. To measure basal and insulin-stimulated glucose transport, muscle strips were incubated in triplicate in Krebs-Henseleit buffer in the absence or presence of $10^{-7} \mathrm{M}$ insulin as previously described (2). Briefly, the muscle strips were preincubated for $30 \mathrm{~min}$ in KrebsHenseleit buffer containing $1 \% \mathrm{BSA}$ and $1.0 \mathrm{mM}$ pyruvate. The strips were then transferred to medium containing $5 \mathrm{mM}$ 2-deoxyglucose, 20 $\mathrm{mM}$ sorbitol, $0.4 \mu \mathrm{Ci} / \mathrm{mmol}\left[{ }^{3} \mathrm{H}\right] 2$-deoxyglucose, and $0.005 \mu \mathrm{Ci} / \mathrm{mmol}$ $\left[{ }^{14} \mathrm{C}\right]$ sorbitol for $10 \mathrm{~min}$. Both incubations were done at $37^{\circ} \mathrm{C}$ with the media continuously gassed with $95 \% \mathrm{O}_{2}, 5 \% \mathrm{CO}_{2}$. After washing twice by incubating for $5 \mathrm{~min}$ in ice-cold Krebs-Henseleit buffer, the samples were blotted, weighed, digested, and counted by liquid scintillation for ${ }^{3} \mathrm{H}$ and ${ }^{14} \mathrm{C}$ radioactivity.

For studies of insulin signaling, additional strips from the same biopsied muscle specimen were preincubated for $30 \mathrm{~min}$ in KrebsHenseleit buffer containing $1 \%$ BSA and $1.0 \mathrm{mM}$ pyruvate. For the insulin-treated muscle, the strips were then transferred to medium containing insulin $\left(10^{-7} \mathrm{M}\right)$ and incubated for $2,4,15$, or $30 \mathrm{~min}$. For basal treatment, the muscle strips were incubated in the absence of insulin for the corresponding times (2-30 $\mathrm{min})$. Three strips were incubated for each condition/time point. After incubation, the muscle strips were rapidly frozen in liquid nitrogen. The three strips from each treatment were pooled and homogenized with a Polytron (Brinkman Instruments, Westbury, $\mathrm{NY}$ ) in ice-cold buffer ( $50 \mathrm{mM}$ Hepes, $\mathrm{pH} 7.5$, $150 \mathrm{mM} \mathrm{NaCl}, 10 \mathrm{mM} \mathrm{NaPP}, 2 \mathrm{mM} \mathrm{Na} \mathrm{VO}_{4}, 1 \mathrm{mM} \mathrm{MgCl}, 1 \mathrm{mM}$ $\mathrm{CaCl}_{2}, 10 \mathrm{mM} \mathrm{NaF}, 2 \mathrm{mM}$ EDTA, $2 \mathrm{mM}$ PMSF, $5 \mu \mathrm{g} / \mathrm{ml}$ leupeptin, $1 \% \mathrm{NP}-40,10 \%$ glycerol). The homogenate was incubated for $45 \mathrm{~min}$ at $4^{\circ} \mathrm{C}$ with gentle mixing and then centrifuged at $35,000 \mathrm{~g}$ for $60 \mathrm{~min}$. The supernatant was collected and assayed for protein concentration using the Bradford dye binding assay kit (31).

Tyrosine phosphorylation of the insulin receptor and IRS-1. For the study of tyrosine phosphoproteins, equal amounts of solubilized proteins $(300 \mu \mathrm{g})$ were resolved by SDS-PAGE and transferred to nitrocellulose membranes using a semidry transfer apparatus (Owl Scientific, Cambridge, MA). To reduce nonspecific antibody binding, the nitrocellulose membranes were blocked with $5 \%$ albumin for $2 \mathrm{~h}$ at $37^{\circ} \mathrm{C}$ in a Tris$\mathrm{NaCl}$ buffer ( $\mathrm{pH} 7.8$ ) containing $0.01 \%$ sodium azide (TNA). The membranes were then incubated with affinity-purified anti-phosphotyrosine antibody $(\alpha \mathrm{PY})(26)$ in TNA plus $5 \%$ BSA for $12-16 \mathrm{~h}$ at $4^{\circ} \mathrm{C}$. The membranes were subjected to two 5-min washes in TNA plus $0.05 \%$ NP-40 and one 5-min wash in TNA plus $0.1 \%$ Tween 20 . Bound antibodies were detected by incubation with ${ }^{125} \mathrm{I}$-labeled protein A (1 $\mu \mathrm{Ci} / \mathrm{ml}$ ) for $1 \mathrm{~h}$ at $25^{\circ} \mathrm{C}$. The membranes were then washed twice, for 10 min each, in TNA plus $0.05 \% \mathrm{NP}-40$ and twice, for $10 \mathrm{~min}$ each, in TNA plus $0.1 \%$ Tween 20 . Quantitation of specific protein bands was determined on a phosphorimager.

PI 3-kinase activity measurements. To determine the effects of obesity on basal and insulin-stimulated PI 3-kinase, enzyme activity was measured in immunoprecipitates obtained with antibodies to IRS-1 ( $\alpha$ IRS-1, affinity-purified polyclonal antibody prepared by injecting rabbits with a synthetic peptide corresponding to the last 14 amino acids in the $\mathrm{COOH}$-terminal region of rat IRS-1). PI 3-kinase activity in 
Table I. Descriptive Data

\begin{tabular}{lcc}
\hline & Lean & Obese \\
\hline$n$ & 8 & 8 \\
Age $(\mathrm{yr})$ & $39.3 \pm 2.3$ & $40.0 \pm 2.0$ \\
Race & $4 \mathrm{AA}, 4 \mathrm{~W}$ & $4 \mathrm{AA}, 4 \mathrm{~W}$ \\
BMI $\left(\mathrm{kg} / \mathrm{m}^{2}\right)$ & $25.7 \pm 0.9$ & $52.9 \pm 3.6^{*}$ \\
Waist/hip ratio & $\mathrm{ND}$ & $0.89 \pm 0.2$ \\
Glucose $(\mathrm{mg} / \mathrm{dl})$ & $92.4 \pm 4.7$ & $105.4 \pm 12.4$ \\
Insulin $(\mu \mathrm{U} / \mathrm{ml})$ & $4.0 \pm 1.0$ & $7.5 \pm 2.1$ \\
\hline
\end{tabular}

Data are mean \pm SE. AA, African-American; $W$, white; ND, not determined. $* P<0.05$ vs lean group.

reconstituted immunoprecipitates was assayed as previously described $(18,32)$ with some modifications. A 2-mg aliquot of extracted muscle proteins (see previously described procedure) was immunoprecipitated with $\alpha$ IRS-1. After incubation with protein A-Sepharose, immunocomplexes were collected by centrifugation, washed three times with PBS containing $1 \% \mathrm{NP}-40$ and $100 \mu \mathrm{M} \mathrm{Na} \mathrm{VO}_{4}$, three times with $100 \mathrm{mM}$ Tris- $\mathrm{HCl}(\mathrm{pH} 7.5)$ containing $500 \mathrm{mM} \mathrm{LiCl}_{2}$, and two times with 10 $\mathrm{mM}$ Tris (pH 7.5) containing $0.1 \mathrm{M} \mathrm{NaCl}, 1 \mathrm{mM}$ EDTA, and $100 \mathrm{mM}$ $\mathrm{Na}_{3} \mathrm{VO}_{4}$. The pellet was resuspended in $50 \mu \mathrm{l}$ of Tris- $\mathrm{NaCl}$ buffer, and $12 \mathrm{mM} \mathrm{MgCl} 2$ and phosphatidylinositol $(10 \mu \mathrm{g})$ were added. The PI 3-kinase reaction was performed at room temperature and was started by adding $10 \mu \mathrm{l}$ of $440 \mu \mathrm{M}$ ATP containing $30 \mu \mathrm{Ci}$ of [ $\left.{ }^{32} \mathrm{P}\right] \mathrm{ATP}$. After 10 min of vigorous vortexing, the reaction was stopped by the addition of $20 \mu \mathrm{l}$ of $8 \mathrm{~N} \mathrm{HCl}$ and $160 \mu \mathrm{l}$ of $\mathrm{CHCl}_{3} / \mathrm{CH}_{3} \mathrm{OH}(1: 1)$. The phases were separated by centrifugation, and $50 \mu \mathrm{l}$ of the lower organic phase containing the reaction products was spotted on an aluminum-backed silicon TLC plate pretreated with oxalate. The lipids were resolved by chromatography in $\mathrm{CH}_{3} \mathrm{OH} / \mathrm{CHCl}_{3} / \mathrm{H}_{2} \mathrm{O} / \mathrm{NH}_{4} \mathrm{OH}(60: 47: 11.3: 2)$ and visualized by autoradiography. The radioactivity in the spots that comigrated with a PI 3-phosphate standard was quantitated by densitometry.

Insulin receptor, IRS-1, and p85 protein content. To determine the content of the insulin receptor, IRS-1, and p85 subunit of PI 3-kinase, muscle extracts were prepared from muscle samples that were frozen in liquid nitrogen at the time of surgery without incubation. For determination of IRS-1 and p85, $\sim 1 \mathrm{~g}$ of the frozen muscle was powdered with a mortar and pestle, homogenized in ice-cold buffer $(50 \mathrm{mM}$ Hepes pH 7.5, $150 \mathrm{mM} \mathrm{NaCl}, 10 \mathrm{mM} \mathrm{NaPP}, 2 \mathrm{mM} \mathrm{Na}_{3} \mathrm{VO}_{4}, 1 \mathrm{mM} \mathrm{MgCl}$, $1 \mathrm{mM} \mathrm{CaCl} 2,10 \mathrm{mM} \mathrm{NaF}, 2 \mathrm{mM}$ EDTA, $2 \mathrm{mM}$ PMSF, $5 \mu \mathrm{g} / \mathrm{ml}$ leupeptin, $1 \%$ NP-40, $10 \%$ glycerol), and processed as previously described for the $\alpha$ PY studies. To detect insulin receptor protein by immunoblotting, crude membranes were prepared from the untreated frozen muscle specimens. Approximately $0.5 \mathrm{~g}$ of muscle was homogenized in ice-cold buffer ( $250 \mathrm{mM}$ sucrose, $10 \mathrm{mM}$ Tris, $\mathrm{pH} 8.0$, containing $10 \mathrm{mM}$ DTT). After centrifugation at $1,000 \mathrm{~g}$ for $15 \mathrm{~min}$ to remove large debris and nuclei, the supernatant was centrifuged at $200,000 \mathrm{~g}$ for $45 \mathrm{~min}$ at $4^{\circ} \mathrm{C}$. The pellet was resuspended in the sucrose-Tris buffer, and protein concentration was measured using the Bradford dye binding assay kit (31).

Immunoblotting procedures for the detection of the insulin receptor and p85 proteins were as previously described for immunoblotting with $\alpha \mathrm{PY}$. For insulin receptor immunoblotting, an affinity-purified $\mathrm{COOH}-$ terminal anti-peptide antibody was used $(\alpha \mathrm{IRCt})(26)$. For detection of the p85 protein, a polyclonal antibody directed against the $85-\mathrm{kD}$ subunit of PI 3-kinase was used ( $\alpha$ p85). Immunoblotting of the IRS-1 protein was done using an affinity-purified anti-peptide antibody ( $\alpha$ IRS1C) (33). For IRS-1 immunoblotting, nonspecific antibody binding was reduced by incubating in 5\% milk (TNA containing 5\% Carnation nonfat powdered milk and $0.2 \%$ Tween 20 ) for $2 \mathrm{~h}$ at $25^{\circ} \mathrm{C}$. Specific antibody binding was done with $\alpha$ IRS-1C in TNA plus $1 \%$ milk and $0.2 \%$ Tween

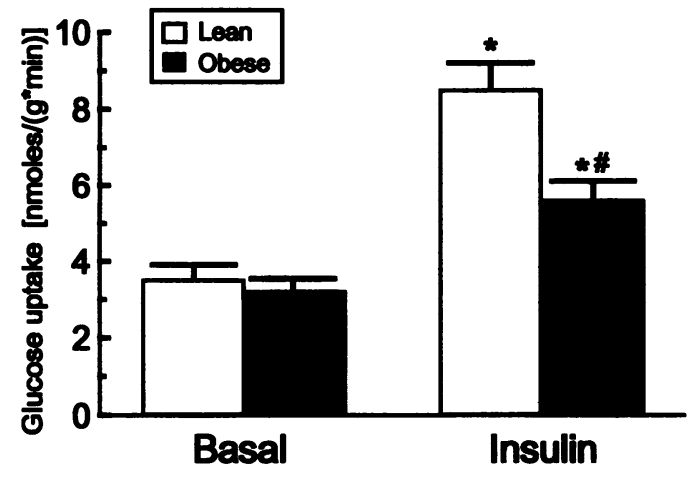

Figure 1. Basal and insulin-stimulated glucose uptake in human skeletal muscle. Rectus abdominus muscle was removed from eight lean and eight obese subjects undergoing abdominal surgery. Multiple muscle strips were teased from the muscle specimen and incubated under basal conditions or in the presence of insulin $\left(10^{-7} \mathrm{M}\right)$ as described in Methods. Data are mean $\pm S E$. * Significantly different from the corresponding basal value $(P<0.01)$; \# significantly different from the corresponding lean value $(P<0.05)$.

20. Bound antibodies were detected with ${ }^{125} \mathrm{I}$-labeled protein A as previously described.

Statistical analyses. All data are expressed as mean \pm SE. Differences between the lean and obese groups were determined using an unpaired Student's $t$ test.

\section{Results}

Subject characteristics and glucose uptake measurements. The clinical characteristics of the subjects are shown in Table I. Age and racial makeup were similar in the two groups. The body mass index (BMI) for the control, non-obese group was 25.7 $\mathrm{kg} / \mathrm{m}^{2}$, whereas that for obese group indicates severe obesity, with BMIs ranging from 41 to $67 \mathrm{~kg} / \mathrm{m}^{2}$. Glucose and insulin concentrations measured in the fasted state were not statistically different between the lean and obese subjects (Table I).

Glucose uptake was measured in strips of rectus abdominus muscle obtained during surgery. Muscle strips from each subject were incubated in the absence or presence of $10^{-7} \mathrm{M}$ insulin, and glucose uptake was measured using $\left[{ }^{3} \mathrm{H}\right] 2$-deoxyglucose. Basal rates of glucose uptake in the muscle strips were not different in the lean and obese groups (Fig. 1). In contrast, insulin-stimulated glucose uptake was significantly lower in muscles from the obese subjects as compared with the lean subjects $(P<0.05)$.

Insulin receptor and IRS-1 tyrosine phosphorylation and protein content. Preliminary experiments were done on rectus abdominus muscle strips obtained from three lean subjects. To determine whether insulin stimulates tyrosine phosphorylation of the insulin receptor $\beta$ subunit and IRS-1 in intact human skeletal muscle, strips were incubated in buffer containing insulin $\left(10^{-7} \mathrm{M}\right)$ for 2,4 , or $15 \mathrm{~min}$. Figure 2 is a representative autoradiograph from one subject showing that insulin incubation increased tyrosine phosphorylation of two major proteins, one with a molecular mass of $\sim 95 \mathrm{kD}$ and one with a molecular mass of $\sim 170 \mathrm{kD}$. Subsequent experiments using specific antibodies to the insulin receptor $\beta$ subunit $(\alpha \mathrm{IRCt})$ and IRS-1 $(\alpha$ IRS-1C) demonstrated that the two major insulin-stimulated tyrosine phosphoproteins, pp95 and pp170, are the $\beta$ subunit of 


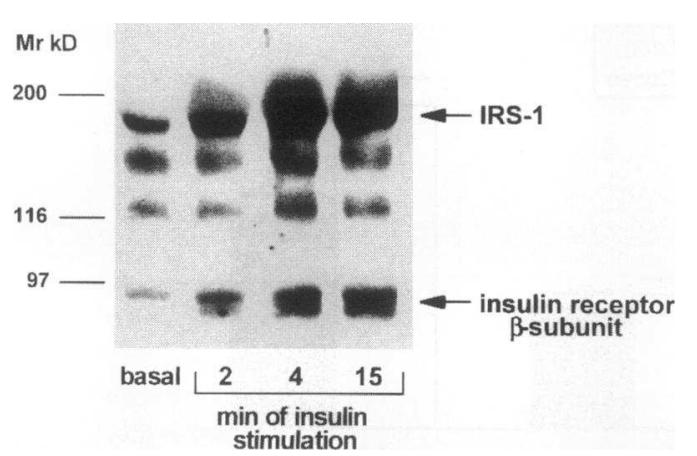

Figure 2. Effect of insulin on insulin receptor and IRS-1 tyrosine phosphorylation in human skeletal muscle. Rectus abdominus muscle was removed from one lean patient undergoing abdominal surgery. Multiple muscle strips were teased from the muscle specimen and incubated under basal conditions or in the presence of insulin $\left(10^{-7} \mathrm{M}\right)$ for 2,4 , or $15 \mathrm{~min}$. Equal amounts $(300 \mu \mathrm{g})$ of solubilized muscle protein prepared from the muscle strips were resolved by SDS-PAGE and immunoblotted with $\alpha \mathrm{PY}$.

the insulin receptor and IRS-1, respectively (data not shown). Similar to our previous studies in rat skeletal muscle, there was a rapid increase in phosphorylation of the insulin receptor and IRS-1 in the human skeletal muscle (26). However, in contrast to studies in the intact rat, in which IRS-1 phosphorylation was transient (returned to basal levels by $4 \mathrm{~min}$ ) (26), there was no decrease in tyrosine phosphorylation of IRS-1 in the human muscle strips after $15 \mathrm{~min}$ of insulin incubation (Fig. 2). In subsequent experiments, muscles strips were incubated for 2 , 15 , or $30 \mathrm{~min}$.

To determine whether there was an effect of obesity on tyrosine phosphorylation of the insulin receptor or IRS-1, muscle strips from eight lean and eight obese subjects were studied in pairs. Incubated muscle strips from one lean subject and one obese subject were homogenized and processed in the same experiment, and equal amounts of muscle proteins were loaded and separated on the same gel. Figure 3 is a representative experiment showing a decreased level of tyrosine phosphoproteins in the obese subject and decreased insulin-stimulated tyrosine phosphorylation of both the insulin receptor and IRS-1. Quantitative data for all eight lean and eight obese subjects

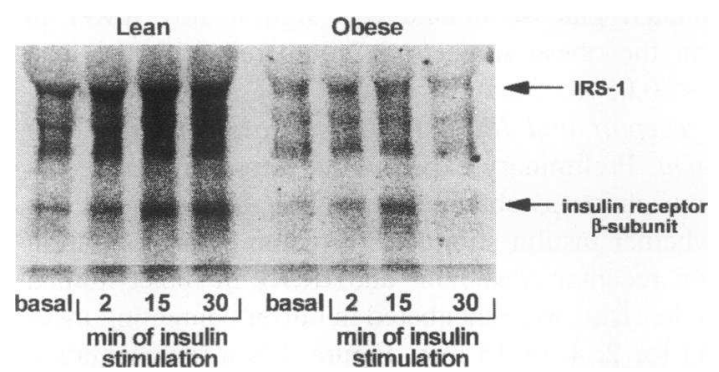

Figure 3. Insulin receptor and IRS-1 tyrosine phosphorylation in skeletal muscle from lean and obese subjects. This image shows tyrosine phosphoproteins from one lean subject and one obese subject. Multiple muscle strips were incubated in the absence or presence of insulin $\left(10^{-7}\right.$ M) for 2,15 , or $30 \mathrm{~min}$. Equal amounts $(300 \mu \mathrm{g})$ of solubilized muscle protein prepared from the muscle strips were resolved by SDS-PAGE and immunoblotted with $\alpha \mathrm{PY}$.
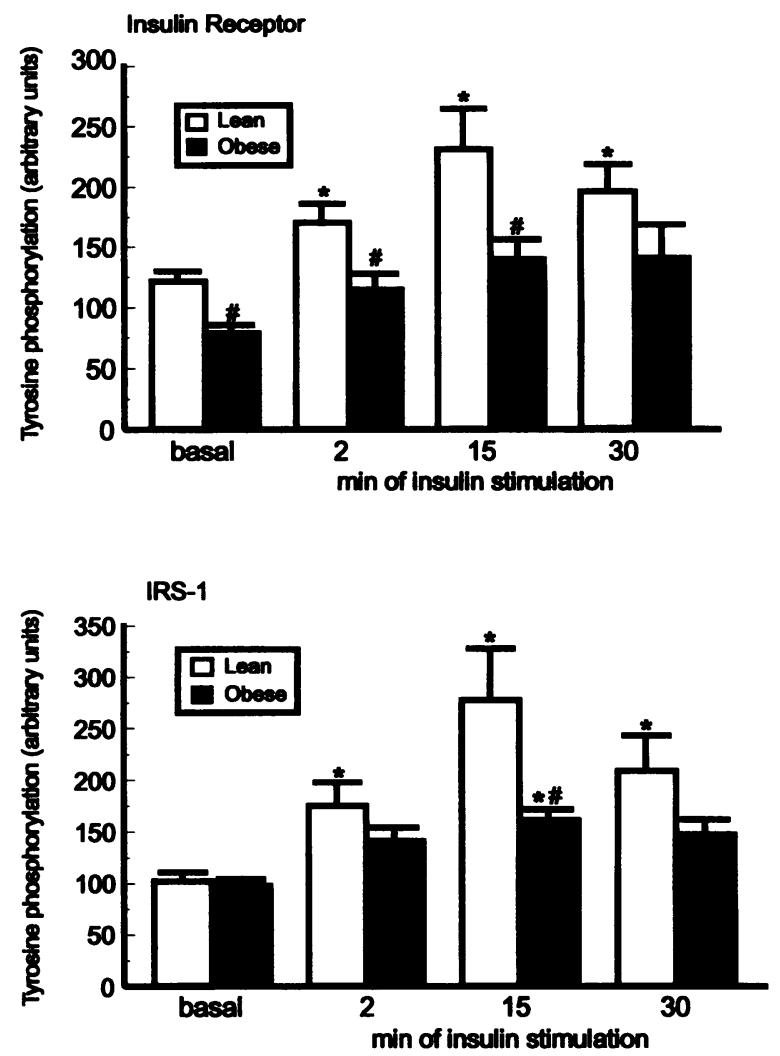

Figure 4. Quantitation of insulin receptor phosphorylation (top) and IRS-1 tyrosine phosphorylation (bottom) in skeletal muscle from lean and obese subjects. Muscle strips were incubated and processed as described in Fig. 2 and in Methods. Muscle strips from one lean subject and one obese subject were processed in the same experiment and separated on the same gel. For each paired experiment, the densitometric units of each basal sample from the lean and obese subjects were averaged and set to $100 \%$. Values for each sample from that gel were then calculated relative to the $100 \%$. Data are mean \pm SE, $n=8$ per group. * Significantly different from the corresponding basal value $(P<0.05)$; \# significantly different from the corresponding lean value $(P<0.05)$.

are shown in Fig. 4. In the lean subjects, insulin significantly increased tyrosine phosphorylation of the insulin receptor $\beta$ subunit at all incubation time points studied (Fig. 4, top). In the obese subjects, insulin-stimulated receptor phosphorylation was lower, with only the 15 -min incubation time point close to a statistically significant elevation $(P=0.06)$. Likewise, insulin increased IRS-1 tyrosine phosphorylation at all incubation times in the lean subjects, whereas phosphorylation was significantly increased only with $15 \mathrm{~min}$ of insulin incubation in the obese subjects (Fig. 4, bottom).

To determine whether the decrease in receptor and IRS-1 phosphorylation in the obese subjects was associated with a decreased expression of these proteins, we measured the relative abundance of the insulin receptor and IRS-1 in the skeletal muscle samples. As illustrated in the phosphoimages in Figs. 5 and 6 , there was considerable variability in insulin receptor and IRS-1 protein levels among the lean subjects. When insulin receptor and IRS-1 protein content of the eight lean and eight obese subjects was calculated by densitometry, the mean levels of both the insulin receptor and IRS-1 proteins were slightly 

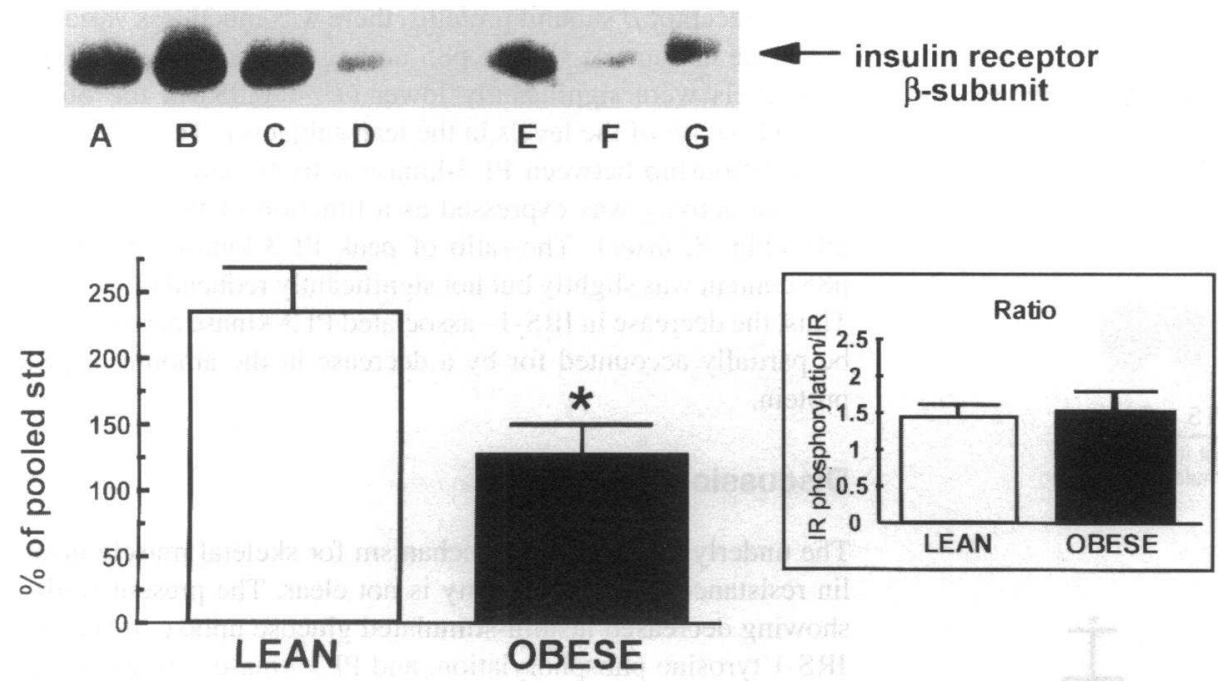

Figure 5. Insulin receptor protein content in human skeletal muscle. The image shows immunoreactive IRS-1 from four individual lean subjects (left, $A-D$ ) and three individual obese subjects (right, $E$ $G)$. The bar graph on the left is quantitation from 14 lean and 11 obese subjects. The inset is insulin receptor tyrosine phosphorylation per insulin receptor protein, which was calculated from the peak tyrosine phosphorylation from the eight lean and eight obese subjects and expressed as a ratio. Muscle extracts were prepared from frozen muscle samples as described in Methods. Immunoblotting was done as described in Methods using $\alpha$ IRCt. Data are mean \pm SE. * Significantly different from the lean value ( $P$ $<0.05$ ). higher in the lean compared with the obese subjects (data not shown), but these differences did not reach statistical significance $(P=0.08)$. To determine whether there was a clear difference in receptor and IRS-1 levels between lean and obese subjects, we measured insulin receptor protein in six additional lean and three additional obese subjects. These subjects were similar to the 16 subjects characterized in Table I, but had only frozen, untreated muscle samples obtained at the time of surgery.

Figure 5 (top) is a representative phosphoimage showing the insulin receptor protein from four individual lean and three obese subjects. The bar graph on the left summarizes the data from all 14 lean and 11 obese subjects. There was a significant decrease in insulin receptor levels in the obese subjects $(55 \%$ of lean; $P<0.05$ ). To examine the relationship between insulin receptor phosphorylation and insulin receptor protein, we expressed receptor phosphorylation as a function of the amount of receptor protein in each subject (Fig. 5, inset). This ratio was calculated by dividing the peak tyrosine phosphorylation from each of the eight subjects (2-, 15-, or 30-min time point) by the receptor protein from each of these subjects. The similar ratio in the lean and obese subjects suggests that the decrease in tyrosine-phosphorylated receptor may largely be explained by the decrease in the abundance of the insulin receptor protein.

Figure 6 (top) is a representative phosphoimage showing immunoreactive IRS-1 from four individual lean subjects (left) and four individual obese subjects (right). As with the insulin receptor, there was considerable variability in IRS-1 among the lean subjects. The bar graph on the left summarizes the data from the 14 lean and 11 obese subjects for each group. IRS-1 levels were $46 \%$ lower in the obese subjects as compared with the lean $(P<0.05)$. The inset shows IRS-1 tyrosine phosphorylation per IRS-1 protein, calculated from the peak tyrosine phosphorylation from the eight subjects for each group and expressed as a ratio (Fig. 6 , inset). As with the insulin receptor protein, the similar ratio in the lean and obese subjects suggests that the decrease in IRS-1 is largely responsible for the decrease in insulin-stimulated tyrosine phosphorylation of IRS-1.

PI 3-kinase activity and p85 content. Basal and insulinstimulated PI 3-kinase activity was measured in IRS-1 immunoprecipitates. The same muscle extracts that were used for the detection of tyrosine phosphoproteins were used to measure enzyme activity in basal muscles and in muscles that were incubated with $10^{-7} \mathrm{M}$ insulin for 2,15 , or 30 . A representative
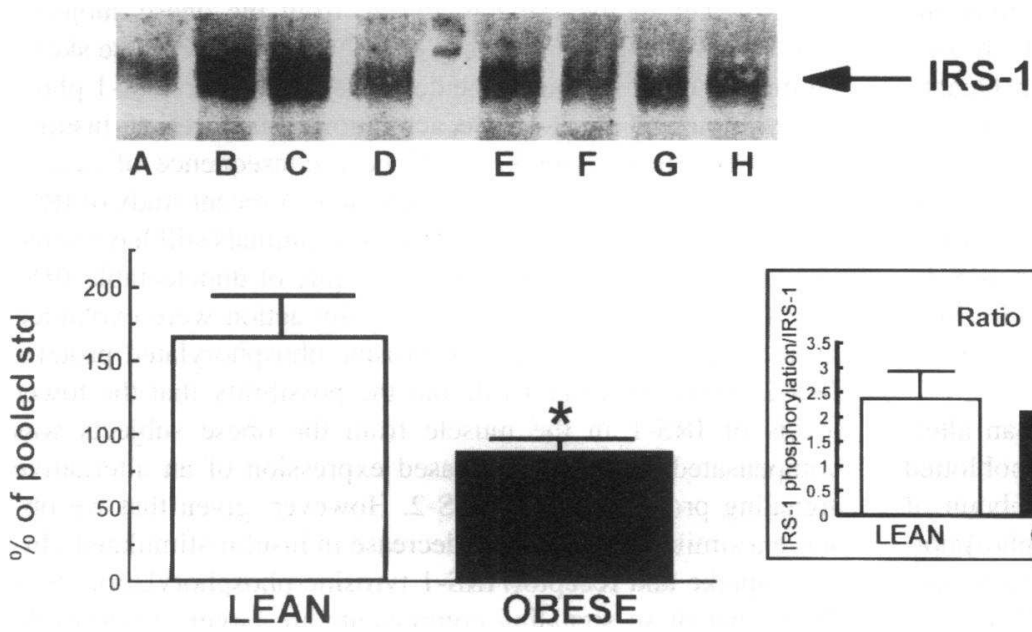

Figure 6. IRS-1 protein content in human skeletal muscle. The image shows immunoreactive IRS-1 from four individual lean subjects (left, $A-D)$ and four individual obese subjects (right, $E-H$ ). The bar graph on the left is quantitation from 14 lean and 11 obese subjects. The inset is IRS-1 tyrosine phosphorylation per IRS-1 protein, which was calculated from the peak tyrosine phosphorylation from the eight lean and eight obese subjects and expressed as a ratio. Muscle extracts were prepared from frozen muscle samples as described in Methods. Immunoblotting was done as described in Methods using $\alpha$ IRS-1C. Data are mean \pm SE. * Significantly different from the lean value $(P<0.05)$. 

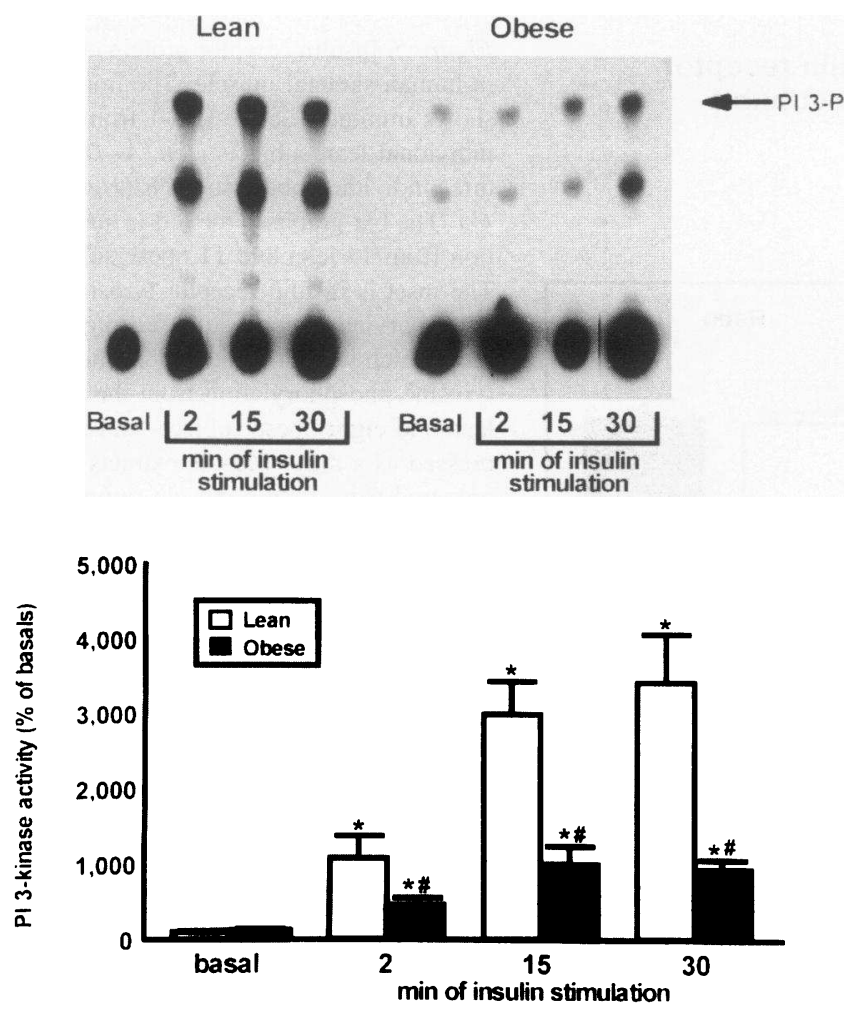

Figure 7. PI 3-kinase activity (IRS-1 immunoprecipitable) in skeletal muscle from lean and obese subjects. Equal amounts $(2 \mathrm{mg})$ of solubilized protein were immunoprecipitated with $\alpha$ IRS-1. The kinase reaction was performed in the presence of phosphatidylinositol and $\left[{ }^{32} \mathrm{P}\right] \mathrm{ATP}$, and the lipid products were separated by TLC (top). The spots that comigrated with a PI 3-phosphate (PI 3-P) standard were quantitated by densitometry (bottom). For each paired experiment, the densitometric units of the basal samples from the lean and obese subjects were averaged and set to $100 \%$, as described in Fig. 4. Data are mean \pm SE; $n=8$ per group. ${ }^{*}$ Significantly different from the corresponding basal value $(P<0.05)$; \# significantly different from the corresponding lean value $(P<0.05)$.

TLC phosphoimage of IRS-1 -immunoprecipitable PI 3-kinase activity from the skeletal muscle of one lean subject and one obese subject is shown in Fig. 7 (top). In the lean subject, insulin markedly increased IRS-1 - associated PI 3-kinase activity at all time points. Following the same pattern as receptor and IRS-1 tyrosine phosphorylation, in the obese subject, insulinstimulated PI 3-kinase activity was significantly lower. Quantitation of the IRS-1-associated PI 3-kinase activity from all of the subjects shows that insulin increased enzyme activity by $\sim 10$ - to 35 -fold in the lean subjects (Fig. 6, bottom). In the obese subjects, insulin significantly increased PI 3-kinase activity at all time points studied. However, the increase in IRS-1associated enzyme activity was significantly lower in the obese as compared with the lean subjects, increasing to only four- to tenfold above basal activity.

To determine whether obesity is associated with an alteration in the amount of PI 3-kinase protein, we immunoblotted the skeletal muscle samples for the p85 regulatory subunit of the PI 3-kinase enzyme (Fig. 8). The representative phosphoimage in Fig. 8 shows the p85 protein from four lean (left) and three obese (right) subjects. In comparison with the IRS-1 and insulin receptor $\beta$ subunit proteins, there was much less variability in the amount of muscle p85 among the lean subjects. The p85 levels were significantly lower $(P<0.05)$ in the obese subjects ( $64 \%$ of the levels in the lean subjects). To understand the relationship between PI 3-kinase activity and p85 protein, enzyme activity was expressed as a function of the amount of p85 (Fig. 8, inset). The ratio of peak PI 3-kinase activity to p85 content was slightly but not significantly reduced $(P=0.1)$. Thus, the decrease in IRS-1 - associated PI 3-kinase activity may be partially accounted for by a decrease in the amount of p85 protein.

\section{Discussion}

The underlying molecular mechanism for skeletal muscle insulin resistance in human obesity is not clear. The present study, showing decreased insulin-stimulated glucose uptake, receptor/ IRS-1 tyrosine phosphorylation, and PI 3-kinase activity in the same intact muscle, strongly suggests that impairment of initial steps in insulin signaling contributes to the defect in insulinstimulated skeletal muscle glucose uptake. To our knowledge, these are the first results obtained in intact human skeletal muscle tissue showing that multiple steps of the insulin receptor signaling pathway are altered in obese, insulin-resistant subjects. These results support the concept that fully functional insulin receptor phosphorylation, IRS-1 phosphorylation, and PI 3-kinase activation are required for normal insulin stimulation of glucose uptake. Evidence for this hypothesis was originally provided by studies in Chinese hamster ovary cells, in which impairment of insulin-stimulated receptor kinase activity by mutation of the tyrosine kinase domain (34) or ATP-binding region $(35,36)$ resulted in decreased insulin-stimulated glucose uptake. More recent studies have shown that inhibition of PI 3kinase activation blocks insulin-stimulated glucose uptake and GLUT-4 translocation in 3T3-L1 adipocytes $(21,37)$ and CHOGLUT4myc cells (23). Although none of these studies demonstrated a direct link between insulin receptor signaling and glucose transport, taken together they provide a strong case for a role of these signaling steps in insulin regulation of glucose uptake. Our data demonstrating that the defect in insulin-stimulated glucose uptake is associated with reduced activation of the initial steps in insulin signaling in skeletal muscle suggest a coupling of these mechanisms in this human tissue.

Although insulin-stimulated glucose uptake was significantly lower in the skeletal muscle from the obese subjects, insulin still increased rates of glucose uptake in the obese skeletal muscle by $65 \%$. Given the decrease in receptor/IRS-1 phosphorylation and PI 3-kinase activation, this level of insulinstimulated glucose uptake could be a consequence of insulin activating alternative signaling pathways. A recent study of IRS1-deficient mice has revealed that these animals still have some insulin-stimulated glucose uptake in spite of undetectable IRS1 (38). These residual levels of insulin action were explained by the appearance of a novel tyrosine-phosphorylated protein, IRS-2. Thus, we cannot rule out the possibility that the lower levels of IRS-1 in the muscle from the obese subjects was compensated for by an increased expression of an alternative signaling protein, such as IRS-2. However, given that we observe a similar magnitude of decrease in insulin-stimulated glucose uptake and receptor/IRS-1 tyrosine phosphorylation, it is likely that these signaling components are largely responsible 

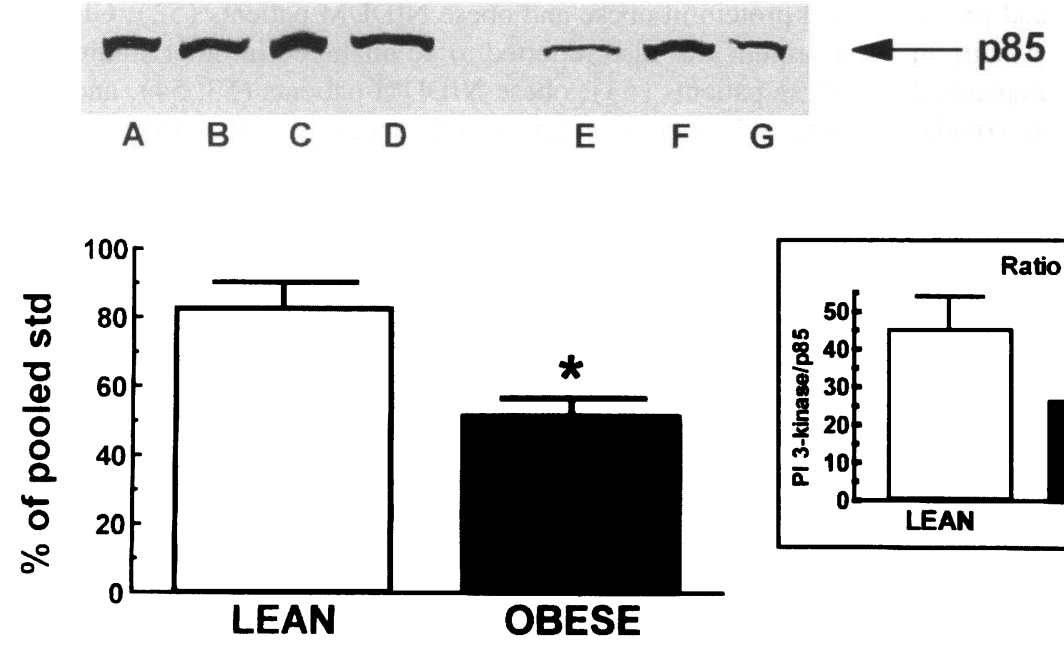

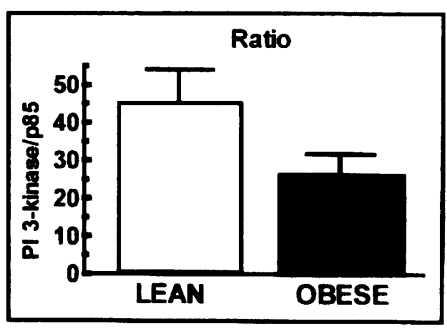

for the residual amount of insulin-stimulated glucose uptake in the muscle from the obese subjects.

The decrease in the insulin signal could be a consequence of the lower levels of the insulin receptor, IRS-1, and PI 3kinase proteins in the skeletal muscle from the obese subjects. This decrease in insulin receptor expression in obesity is consistent with previous studies showing significant or modest decreases in insulin binding in the skeletal muscle (25), liver (39), and adipose tissue $(40,41)$ of obese subjects. Before the results presented in the current study, levels of IRS-1 and PI 3kinase proteins had not been reported in tissues from insulinresistant subjects. The concept that decreased insulin signaling is a result of decreased expression of the signaling proteins is based on the mean stoichiometry of insulin receptor phosphorylation, IRS-1 phosphorylation, and PI 3-kinase activity. For example, the similar obesity-associated decreases in tyrosine phosphorylation of the insulin receptor and insulin receptor protein levels suggest that the average amount of tyrosine phosphorylation per receptor is not decreased in the obese subjects.

Although the current study suggests that the obesity-associated decreases in early steps of the insulin signaling pathway are largely due to decreased levels of the insulin receptor, IRS1, and PI 3-kinase proteins, other forms of insulin resistance may be associated with decreases in both the expression and function of these proteins. In the skeletal muscle from lean patients with NIDDM, autophosphorylation of isolated insulin receptors was reduced by twofold, and kinase activity toward the exogenous substrate poly(Glu4:Tyr1) was decreased by threefold (24). Since these experiments used an in vitro assay system that equalizes insulin receptor protein, the defect in receptor kinase activity could not be attributable to an alteration in the number of insulin receptors. In a study of obese subjects with NIDDM, insulin receptor autophosphorylation was not altered, but receptor phosphorylation of poly(Glu4:Tyr1) was decreased by $>50 \%$ (25). However, the defect in receptor kinase activity toward the exogenous substrate was similar in nondiabetic obese patients (25). Understanding the discrepancies among the two in vitro studies and the current study is difficult, since the patient population and/or methodologies are very different. Overall, however, all three studies demonstrate that insulin-resistant skeletal muscle is characterized by some degree of defect in insulin receptor tyrosine phosphorylation.
Figure 8. p85 protein content in human skeletal muscle. The image shows immunoreactive IRS-1 from four individual lean subjects (left, $A-D$ ) and three individual obese subjects (right, $E-G$ ). The bar graph on the left is quantitation from 14 lean and 11 obese subjects. The inset is PI 3-kinase activity (IRS-1 immunoprecipitable) per $\mathrm{p} 85$ protein, which was calculated from the peak PI 3-kinase activity from the eight lean and eight obese subjects and expressed as a ratio. Muscle extracts were prepared from frozen muscle samples as described in Methods. Immunoblotting was done as described in Methods using $\alpha \mathrm{p} 85$. Data are mean \pm SE. * Significantly different from the lean value $(P<0.05)$.
In future research it will be important to study patients with NIDDM using the intact human skeletal muscle preparation.

The obesity-associated decreases in insulin receptor signaling and PI 3-kinase activity in human skeletal muscle are generally similar to findings reported in animal models of obesity $(27,42)$. In the obese, hyperglycemic, and hyperinsulinemic $o b / o b$ mouse, in vivo insulin-stimulated tyrosine phosphorylation of the receptor and IRS-1 was decreased by $\sim 40$ and $50 \%$, respectively (27). In contrast to our findings in human skeletal muscle, in which both insulin receptor and IRS-1 protein levels were decreased, in the skeletal muscle of this mouse strain there was a decrease only in insulin receptor protein levels. Thus, in the obese mouse, the decrease in IRS-1 phosphorylation may be more a consequence of impaired insulin receptor kinase activity, whereas in human skeletal muscle, the decrease may be a function of both reduced receptor kinase activity and decreased IRS1 protein levels. In mice made obese by goldthioglucose, there was a $40-60 \%$ decrease in insulin-stimulated PI 3-kinase activity immunoprecipitated with an anti-phosphotyrosine antibody (42). Although obesity did not result in a decrease in "total" (anti-p85 immunoprecipitable) PI 3-kinase activity, PI 3-kinase protein amounts were not measured. Thus, it is difficult to determine whether, as with human skeletal muscle, the decreased IRS-1-associated PI 3-kinase activity in the obese mice is a function of decreased expression of $\mathrm{p} 85$.

The mechanism for decreased expression of signaling proteins in insulin-resistant patients could be a function of elevations in blood insulin or glucose. In the current study the obesity-associated decreased expression of the insulin receptor, IRS-1, and p85 occurred in the absence of statistically significant elevations in blood glucose and insulin. However, it is important to recognize that although not statistically significant, insulin concentrations were $88 \%$ higher in the obese group, similar to our previous findings $(36,43)$. Furthermore, since glucose tolerance testing was not performed, it is possible that some or all of the obese subjects had elevated postprandial glucose and/or insulin concentrations (44). Nevertheless, our data demonstrate that defects in insulin signaling components and insulin-stimulated glucose uptake in skeletal muscle from severely obese subjects can occur before the onset of frank hyperglycemia.

One possible mechanism to explain the obesity-associated 
decreased expression of the insulin receptor, IRS-1, and p85 is that lower levels of these proteins are caused by a shift in muscle fiber type composition. We have recently demonstrated a significantly lower percentage of slow twitch fibers (oxidative) and a tendency for an increase in type IIb fibers (fast, glycolytic) in a similar group of obese subjects (44a). In rats, slow twitch fibers have higher levels of insulin receptor binding compared with fast twitch fibers $(45,46)$. Thus, lower levels of type I fibers in the obese subjects may result in an overall decrease in insulin receptor expression. The alteration in fiber type composition may also result in the lower levels of IRS-1 and $\mathrm{p} 85$ protein, although this is speculative, since to our knowledge there have been no published reports comparing IRS-1 and p85 levels in slow and fast twitch muscles. It is important to note that the obesity-associated decrease in the expression of these specific signaling proteins probably does not reflect a generalized decrease in all muscle proteins. In comparing the lean and obese subjects in the current study, there was no difference in the estimated recovery of total muscle protein between the two groups. Furthermore, in preliminary studies of a subset of the subjects in the current study, we did not detect an alteration in the expression of two isoforms of microtubule-associated protein kinase (Markuns, J. F., and L. J. Goodyear, unpublished observations).

Although the decreased expression of the insulin receptor, IRS-1, and PI 3-kinase proteins may largely explain the obesityassociated decreases in receptor/IRS-1 phosphorylation and PI 3-kinase activity, it is possible that other cellular regulatory factors contribute to the down-regulation of these signaling reactions. For example, increased serine phosphorylation of the insulin receptor has been shown to decrease receptor tyrosine kinase activity (47), and serine phosphorylation of the p85 regulatory subunit of PI 3-kinase significantly decreases enzyme activity $(48,49)$. Serine phosphorylation of p85 by PI 3-kinase kinase in vitro decreases enzyme activity by three- to sevenfold, an effect that can be reversed by dephosphorylation with phosphoprotein phosphatase $2 \mathrm{~A}$ (49). Thus, the obese state may result in an increase in PI 3-kinase kinase, a decrease in phosphoprotein 2A activity, or both. The down-regulation of the insulin signal could also be a function of an increase in protein tyrosine phosphatase (PTPase) activity. The findings of one study support this concept, showing a $33 \%$ increase in muscle PTPase activity in obese insulin-resistant subjects (50). On the other hand, another recent report has demonstrated a 21-22\% decrease in muscle PTPase activity in obese nondiabetic and NIDDM subjects (51). A putative role for cellular phosphatases in the regulation of insulin signaling reactions and skeletal muscle insulin resistance will require further investigation.

Our data, taken together with studies in cultured cells (21$23,34-36$ ), suggest that decreased activity of early steps in insulin receptor signaling with obesity is a factor in the lower rates of skeletal muscle glucose uptake. A blunted insulin signal may lead to a block in the activation of glucose transporter function, or may occur in parallel with an independent effect of obesity on the glucose transport system. Any effect of obesity on the glucose transport system is probably at the level of transporter translocation, since effects on the expression of glucose transporter proteins appear to be minimal $(43,52-54)$. In severely obese patients, we have seen only a modest, $23 \%$ decrease in skeletal muscle GLUT-4 protein (43), whereas another report showed no change in GLUT-1 and GLUT-4 mRNA and protein in obese and obese NIDDM patients (52). GLUT4 protein was also reported to be unaltered in other studies on obese patients $(53)$, obese NIDDM patients $(53,54)$, and patients with impaired glucose tolerance (53). The effect of obesity on skeletal muscle glucose transporter translocation has not been determined in human skeletal muscle. However, in the obese Zucker rat, in which both transporter expression and function can be measured, GLUT-4 levels were not altered (55, 56) but insulin-stimulated glucose transporter translocation was impaired (56). Thus, human obesity may also be associated with a defect in GLUT-4 translocation.

Given the consistent findings of decreased levels of signaling proteins in subjects with obesity $(25,39-41$, current study), the recent advances in understanding the insulin signaling pathways (57), and the current knowledge of glucose transporter physiology $(56,58)$, it is possible to propose a series of events that lead to the impaired insulin-stimulated glucose uptake in human skeletal muscle. First, the obese state is associated with a mild to severe decrease in the muscle content of various signaling proteins, including the insulin receptor, IRS-1, and the p85 subunit of PI 3-kinase. Decreased levels of these proteins could lead to diminished phosphorylation reactions and decreased insulin-stimulated activation of PI 3-kinase. The blunting of PI 3-kinase activity could then lead to decreased signaling via specific branches of the insulin signaling pathway, including the transmission of the signal that activates the movement of glucose transporters to the plasma membrane. Finally, the defect in transporter translocation would result in decreased glucose uptake.

In summary, we have developed a procedure to assess both glucose uptake and initial steps in insulin signaling in intact human skeletal muscle. Among the advantages of these methods is the ability to study intact tissue rather than partially purified receptor preparations. We have shown that in the skeletal muscle from obese subjects, there is decreased content and tyrosine phosphorylation of the insulin receptor $\beta$ subunit, decreased content and tyrosine phosphorylation of IRS-1, decreased content of the p85 subunit of PI 3-kinase, and decreased PI 3kinase activity associated with IRS-1. Future studies in human skeletal muscle will focus on determining whether this downregulation of the insulin signaling pathway with obesity plays a role in decreased glucose uptake by altering the functional properties of glucose transporter proteins.

\section{Acknowledgments}

We are grateful to Drs. Judy Treadway and Michael Gibbs (Pfizer Central Research, Groton, CT) for the gift of $\alpha$ IRS-1C. We appreciate the excellent technical assistance of Jeffrey F. Markuns (Joslin Diabetes Center).

This work was supported by a pilot and feasibility grant as part of National Institutes of Health (NIH) Diabetes and Endocrine Research Center grant DK36836 (L. J. Goodyear), a grant from the American Diabetes Association (L. J. Goodyear), NIH grant DK46121 (G. L. Dohm), and NIH grant GM36428 (R. J. Smith). F. Giorgino was the recipient of fellowships from the Juvenile Diabetes Foundation, International, and the Mary K. Iacocca Foundation.

\section{References}

1. DeFronzo, R. A. 1982. Insulin secretion, insulin resistance, and obesity. Int. J. Obes. 6:73-82. 
2. Dohm, G. L., E. B. Tapscott, W. J. Pories, D. J. Dabbs, E. G. Flickinger, D. Meelheim, T. Fushiki, S. M. Atkinson, E. W. Elton, and J. F. Caro. 1988. An in vivo human muscle preparation suitable for metabolic studies. Decreased insulin stimulation of glucose transport in muscle from morbidly obese and diabetic subjects. J. Clin. Invest. 82:486-494.

3. Caro, J. F., L. G. Dohm, W. J. Pories, and M. K. Sinha. 1989. Cellular alteration in liver, skeletal muscle, and adipose tissue responsible for insulin resistance in obesity and type II diabetes. Diabetes Metab. Rev. 5,8:1-25.

4. DeFronzo, R. 1988. The triumvirate: beta-cell, muscle, liver. A collusion responsible for NIDDM. Diabetes. 37:667-687.

5. Farranni, E., O. Bjorkman, G. A. Reichard, Jr., A. Pilo, M. Olsson, J. Wahren, and R. A. DeFronzo. 1985. The disposal of an oral glucose load in health subjects. A quantitative study. Diabetes. 34:580-588.

6. Kasuga, M., F. A. Karlsson, and C. R. Kahn. 1982. Insulin stimulates the phosphorylation of the $\beta$-subunit of its own receptor. Science (Wash. DC). 217:185-187

7. Petruzzelli, L. M., S. Ganguly, C. J. Smith, M. U. Cobb, S. Rubin, and O. M. Rosen. 1982. Insulin activates a tyrosine-specific protein kinase in extracts of 3T3-L1 adipocytes and human placenta. Proc. Natl. Acad. Sci. USA. 79:67926796.

8. Yu, K. T., and M. P. Czech. 1984. Tyrosine phosphorylation of the insulin receptor $\beta$ subunit activates the receptor-associated tyrosine kinase activity. $J$. Biol. Chem. 259:5277-5286.

9. Sun, X. J., P. Rothenberg, R. C. Kahn, J. M. Backer, E. Araki, P. A. Wilden, D. A. Cahill, B. J. Goldstein, and M. F. White. 1991. Structure of the insulin receptor substrate IRS-1 defines a unique signal transduction protein. Nature (Lond.). 352:73-77.

10. Shoelson, S. E., S. Chatterjee, M. Chaudhuri, and M. F. White. 1992. YMXM motifs of IRS-1 define the substrate specificity of the insulin receptor kinase. Proc. Natl. Acad. Sci. USA. 89:2027-2031.

11. Backer, J. M., G. G. Schroeder, C. R. Kahn, M. G. Meyers, P. A. Wilden, D. A. Cahill, and M. F. White. 1992. Insulin stimulation of phosphatidylinositol 3kinase activity maps to insulin receptor regions required for endogenous substrate phosphorylation. J. Biol. Chem. 267:1367-1374.

12. Whitman, M., C. P. Downes, M. Keeler, T. Keller, and L. C. Cantley. 1988. Type I phosphatidylinositol kinase makes a novel inositol phospholipid, phosphatidylinositol-3-phosphate. Nature (Lond.). 332:644-646.

13. Giorgetti, S., R. Ballotti, A. Kowalski-Chauvel, S. Tartare, and E. Van Obberghen. 1993. The insulin and insulin-like growth factor-I receptor substrate IRS-1 associates with and activates phosphatidylinositol 3-kinase in vitro. J. Biol. Chem. 268:7358-7364.

14. Auger, K. R., L. A. Sernunian, S. P. Soltoff, P. Libby, and L. C. Cantley. 1989. PDGF-dependent tyrosine phosphorylation stimulates production of novel polyphosphoinositides in intact cells. Cell. 57:167-175.

15. Parker, P. J., and M. D. Waterfield. 1992. Phosphatidylinositol 3-kinase: a novel effector. Cell Growth Differ. 3:747-752.

16. Schu, P. V., T. Kaoru, M. J. Fry, J. H. Stack, M. D. Waterfield, and S. D Emr. 1993. Phosphatidylinositol 3-kinase encoded by yeast VPs34 gene essential for protein sorting. Science (Wash DC). 260:88-91

17. Kelly, K. L., N. B. Ruderman, and K. S. Chen. 1992. Phosphatidylinositol3-kinase in isolated rat adipocytes: activation by insulin and subcellular distribution. J. Biol. Chem. 267:3423-3428.

18. Folli, F., M. J. A. Saad, J. M. Backer, and C. R. Kahn. 1992. Insulin stimulation of phosphatidylinositol 3-kinase activity and association with insulin receptor substrate 1 in liver and muscle of the intact rat. J. Biol. Chem. 267:2217122177.

19. Chen, K. S., J. C. Friel, and N. B. Ruderman. 1993. Regulation of phosphatidylinositol 3-kinase by insulin in rat skeletal muscle. Am. J. Physiol. Endocrinol. Metab. 265:E736-E743.

20. Endemann, G., K. Yonezawa, and R. A. Roth. 1990. Phosphatidylinositol kinase or an associated protein is a substrate for the insulin receptor kinase. $J$. Biol. Chem. 265:396-400.

21. Cheatham, B., C. J. Vlahos, L. Cheatham, L. Wang, J. Blenis, and C. R. Kahn. 1994. Phosphatidylinositol 3-kinase activation is required for insulin stimulation of pp70 S6 kinase, DNA synthesis, and glucose transporter translocation. Mol. Cell. Biol. 14:4902-4911.

22. Clarke, J. F., P. W. Young, K. Yonezawa, M. Kasuga, and G. D. Holman. 1994. Inhibition of the translocation of GLUT1 and GLUT4 in 3T3-L1 cells by the phosphatidylinositol 3-kinase inhibitor, wortmannin. Biochem. J. 300:631635 .

23. Kanai, F., K. Ito, M. Todaka, H. Hayashi, S. Kamohara, K. Ishii, T. Okada, O. Hazeki, M. Ui, and Y. Ebina. 1993. Insulin-stimulated GLUT4 translocation is relevant to the phosphorylation of IRS-1 and the activity of PI3-kinase. Biochem. Biophys. Res. Commun. 195:762-768.

24. Obermaier-Kusser, B., M. F. White, D. E. Pongrato, Z. Su, B. Ermel, C. Mulbacher, and H. U. Haring. 1989. A defective intramolecular autoactivation cascade may cause the reduced kinase activity of the skeletal muscle insulin receptor from patients with non-insulin-dependent diabetes mellitus. J. Biol. Chem. 264:9497-9504.

25. Caro, J. F., M. K. Sinha, S. M. Raju, O. Ittoop, W. J. Pories, E. G. Flickinger, D. Meelheim, and G. L. Dohm. 1987. Insulin receptor kinase in human skeletal muscle from obese subjects with and without noninsulin dependent diabetes. J. Clin. Invest. 79:1330-1337.

26. Giorgino, F., J.-H. Chen, and R. J. Smith. 1992. In vivo tyrosine phosphorylation of a $\mathrm{Mr} 170 \mathrm{kD}$ putative insulin receptor substrate is increased in the skeletal muscle of streptozotocin-induced diabetic rats: role of insulin and glucose. Endocrinology. 130:1433-1444.

27. Saad, M. J. A., E. Eraki, M. Miralpeix, M. F. White, and C. R. Kahn 1992. Regulation of insulin receptor substrate-1 in liver and muscle of animal models of insulin resistance. J. Clin. Invest. 90:1839-1849.

28. Giorgino, F., A. Almahfouz, L. J. Goodyear, and R. J. Smith. 1993. Glucocorticoid regulation of insulin receptor and substrate IRS-1 tyrosine phosphorylation in rat skeletal muscle in vivo. J. Clin. Invest. 91:2020-2030.

29. Burant, C. F., M. K. Treutelaar, and M. G. Buse. 1986. Diabetes-induced functional and structural changes in insulin receptors from rat skeletal muscle. $J$. Clin. Invest. 77:260-270.

30. Block, N., and M. Buse. 1989. Effects of hypercortisolemia and diabetes on skeletal muscle insulin receptor function in vitro and in vivo. Am. J. Physiol. 256:E39-E48.

31. Bradford, M. M. 1976. A rapid and sensitive method for the quantitation of microgram quantities of protein, utilizing the principle of protein-dye binding. Anal. Biochem. 72:248-254.

32. Ruderman, N. B., R. Kapeller, M. F. White, and L. C. Cantley. 1990 Activation of phosphatidylinositol 3-kinase by insulin. Proc. Natl. Acad. Sci. USA. 87:1411-1415.

33. Lamphere, L., and G. E. Lienhard. 1992. Components of signaling pathways for insulin and insulin-like growth factor-I in muscle myoblasts and myotubes. Endocrinology. 131:2196-2202.

34. Ellis, L., E. Clauser, D. O. Morgan, M. Edery, R. A. Roth, and W. J. Rutter. 1986. Replacement of insulin receptor tyrosine residues 1162 and 1163 compromises insulin-stimulated kinase activity and uptake of 2-deoxyglucose. Cell. 45:721-732

35. Chou, C. K., T. J. Dull, D. S. Russell, R. Gherzi, D. Lebwohl, A. Ullrich, and O. M. Rosen. 1987. Human insulin receptors mutated at the ATP-binding site lack protein tyrosine kinase activity and fail to mediate postreceptor effects of insulin. J. Biol. Chem. 262:1842-1847.

36. Ebina, Y., E. Araki, M. Taira, F. Shimada, M. Mori, C. S. Craik, K. Siddle, S. B. Pierce, R. A. Roth, and W. J. Rutter. 1987. Replacement of lysine residue 1030 in the putative ATP-binding region of the insulin receptor abolishes insulin- and antibody-stimulated glucose uptake and receptor kinase activity. Proc. Natl. Acad. Sci. USA. 84:704-708.

37. Welmsley, A. 1988. The dynamics of the glucose transporter. Trends Biochem. Sci. 13:226-231.

38. Araki, E., M. A. Lipes, M. Patti, J. C. Bruning, B. Haag III, R. Johnson, and C. R. Kahn. 1994. Alternative pathway of insulin signalling in mice with targeted disruption of the IRS-1 gene. Nature (Lond.). 372:186-190.

39. Caro, J. F., O. Ittoop, W. J. Pories, D. Meelheim, E. G. Flickinger, F. Thomas, M. Jenquin, J. F. Silverman, P. G. Khazanie, and M. K. Sinha. 1986 Studies on the mechanism of insulin resistance in the liver from humans with noninsulin-dependent diabetes: insulin action and binding in isolated hepatocytes, insulin receptor structure, and kinase activity. J. Clin. Invest. 78:249-258.

40. Freidenberg, G. R., R. R. Henry, H. H. Klein, D. R. Reichart, and J. M. Olefsky. 1987. Decreased kinase activity of insulin receptors from adipocytes of non-insulin-dependent diabetic subjects. J. Clin. Invest. 79:240-250.

41. Sinha, M. K., W. J. Pories, E. G. Flickinger, D. Meelheim, and J. F. Caro. 1987. Insulin-receptor kinase activity of adipose tissue from morbidly obese humans with and without NIDDM. Diabetes. 36:620-625

42. Heydrick, S. J., D. Jullien, N. Gautier, J.-F. Tanti, S. Giorgetti, E. Van Obberghen, and Y. Le Marchand-Brustel. 1993. Defect in skeletal muscle phosphatidylinositol-3-kinase in obese insulin-resistant mice. J. Clin. Invest. 91:13581366.

43. Dohm, G. L., C. W. Elton, J. E. Friedman, P. F. Pilch, W. J. Pories, S. M. Atkinson, Jr., and J. F. Caro. 1991. Decreased expression of glucose transporter in muscle from insulin-resistant patients. Am. J. Physiol. Endocrinol. Metab. 260:E459-E463.

44. Pories, W. J., K. G. MacDonald, Jr., E. J. Morgan, M. K. Sinha, G. L. Dohm, M. S. Swanson, H. A. Barakat, P. G. Khazanie, N. Leggett-Frazier, S. D Long, K. F. O'Brien, and J. F. Caro. 1992. Surgical treatment of obesity and its effect on diabetes: 10-y follow-up. Am. J. Clin. Nutr. 55:582s-585s

44a. Hickey, M.S., J. O. Carey, J. L. Azevedo, J. A. Houmard, W. J. Pories, R. G. Israel, and G. L. Dohm. 1995. Skeletal muscle fiber composition is related to adiposity and in vitro glucose transport in humans. Am. J. Physiol. In press.

45. Bonen, A., M. H. Tan, and W. M. Watson-Wright. 1981. Insulin binding and glucose uptake differences in rodent muscles. Diabetes. 30:702-704.

46. James, D. E., A. Zorzano, M. Boni-Schnetzeler, R. A. Nemenoff, A. 
Powers, P. F. Pilch, and N. B. Ruderman. 1986. Intrinsic differences of insulin receptor kinase activity in red and white muscle. J. Biol. Chem. 261:1439-14944.

47. Takayama, S., M. F. White, and C. R. Kahn. 1988. Phorbol ester-induced serine phosphorylation of the insulin receptor decreases its tyrosine kinase activity. J. Biol. Chem. 263:3440-3457.

48. Dhand, R., I. Hiles, G. Panayotou, S. Roche, M. J. Fry, I. Gout, N. F. Totty, O. Truong, P. Vicendo, K. Yonezawa, M. Kasuga, S. A. Courtneidge, and M. D. Waterfield. 1994. PI 3-kinase is a dual specificity enzyme: autoregulation by an intrinsic protein-serine kinase activity. EMBO (Eur. Mol. Biol. Org.) J. 13:522-533.

49. Carpenter, C. L., K. R. Auger, B. C. Duckworth, W.-M. Hou, B. Schaffhausen, and L. C. Cantley. 1993. A tightly associated serine/threonine protein kinase regulates phosphoinositide 3-kinase activity. Mol. Cell. Biol. 13:16571665.

50. McGuire, M. C., R. M. Fields, B. L. Nyomba, I. Raz, C. Bogardus, N. K. Tonks, and J. Sommercorn. 1991. Abnormal regulation of protein tyrosine phosphatase activities in skeletal muscle of insulin-resistant humans. Diabetes. 40:939-942.

51. Kusari, J., K. A. Kenner, K. Suh, D. E. Hill, and R. R. Henry. 1994. Skeletal muscle protein tyrosine phosphatase activity and tyrosine phosphatase $1 B$ protein content are associated with insulin action and resistance. J. Clin. Invest. 93:1156-1162.
52. Pedersen, O., J. F. Bak, P. H. Andersen, S. Lund, D. E. Moller, J. S. Flier, and B. B. Kahn. 1990. Evidence against altered expression of GLUT1 or GLUT4 in skeletal muscle of patients with obesity or NIDDM. Diabetes. 39:865-870.

53. Garvey, W. T., L. Maianu, J. A. Hancock, A. M. Golichowski, and A. Baron. 1992. Gene expression of GLUT-4 in skeletal muscle from insulin-resistant patients with obesity, IGT, GDM, and NIDDM. Diabetes. 41:465-475.

54. Handberg, A., A. Vaag, P. Damsbo, H. Beck-Nielsen, and J. Vinten. 1990. Expression of insulin regulatable glucose transporters in skeletal muscle from type 2 (non-insulin-dependent) diabetic patients. Diabetologia. 33:625-627.

55. Friedman, J. E., W. M. Sherman, M. J. Reed, C. W. Elton, and G. L. Dohm. 1990. Exercise training increases glucose transporter protein Glut-4 in skeletal muscle of obese Zucker ( $\mathrm{fa} / \mathrm{fa}$ ) rats. FEBS (Fed. Eur. Biochem. Soc.) Lett. 268:13-16.

56. King, P. A., E. D. Horton, M. F. Hirshman, and E. S. Horton. 1992. Insulin resistance in obese Zucker rat $(\mathrm{fa} / \mathrm{fa})$ skeletal muscle is associated with a failure of glucose transporter translocation. J. Clin. Invest. 90:1568-1575.

57. White, M. F., and C. R. Kahn. 1994. The insulin signaling system. J. Biol. Chem. 269:1-4.

58. Goodyear, L. J. 1993. Effects of exercise and insulin on the glucose transport system in skeletal muscle. In Diabetes Mellitus and Exercise. J. Devlin, E. S. Horton, and M. Vranic, editors. Smith-Gordon, London. 13-26. 